Agnieszka WIDAWSKA-STANISZ ${ }^{1}$

\title{
GAMIFICATION IN THE URBAN AREA
}

\begin{abstract}
Present customers are inundated with the advertisement communications from all sides. Most of them, consciously or not, are unnoticed. The authors of advertising projects look for the ways of getting to the receivers in the world with too much information. There are difficulties in reaching the potential receivers of campaigns promoting different kinds of actions in the urban area. It means the promoting the city as tourist attraction, teaching the history of place or involving the residents in caring of aesthetics. Another argument for gamification is the increasing amount of people interested in games. According to research more and more people choose various kinds of games as the form of entertainment. We are attracted by achieved levels, badges and prizes. If it happens in a particular society, motivating us to take action, in amusing atmosphere, the involvement in game appears automatically. A huge interest in games and other mechanisms begins to translate to other areas. Gaming and the elements of games are more often used in the management of relationship with purchasers and building their involvement. The gamification is associated with sale, education and trainings, brand promoting, product promoting, recruitment, administration and management. The goal of paper was the presentation of the essence of gamification concept with the focus on the actions connected with the gamification of the urban area. It was assumed that gamification can be helpful in motivating both residents of cities and tourists to take care of common space, to involve and work out proper habits and attitudes.
\end{abstract}

Keywords: gamification, urban area, purchaser engagement, the management of relations, marketing

\section{INTRODUCTION}

The idea of gamification is not a new one. A lot of tools used today as part of gamification have been already used. "Psychologists have used different kinds of games to the examination of human psyche and the mechanism of behaviour, for many years"2.The researchers of subject point that the attitudes of modern gamification theory can come from both the socialist ideology of work competition and motivating techniques used in the 1990 s in American corporations ${ }^{3}$. Today gamification dominates in entertainment, marketing, human management, training, branding, relationship management and many other areas. The actions using the elements of games are used thanks to the changing of ways of communication, new technologies development and increasing meaning of social media. A modern purchaser, a potential employee, a supplier or a broker looks for something new, something which is interesting for them to come back to this activity, something which has got the element of competition and involvement.

\footnotetext{
${ }^{1}$ Agnieszka Widawska-Stanisz, PhD, Eng., Wydział Zarządzania, Politechnika Częstochowska, Częstochowa, Al. Armii Krajowej 19B, awidawskastanisz@gmail.com, (34) 3250424

${ }^{2}$ P. Tkaczyk, Grywalizacja. Jak zastosować mechanizmy gier w działaniach marketingowych, Helion, Gliwice 2012.

${ }^{3}$ M. Laskowski, Wykorzystanie czynników grywalizacyjnych $w$ tworzeniu aplikacji użyteczności publicznej, Zeszyty Naukowe Uniwersytetu Rzeszowskiego, https://www.ur.edu.pl/file/57419/2.pdf, dostęp:1.10.2015.
} 
Paweł Tkaczyk provides, that „Harvard Business Review has placed the gamification on the list of trends, which cannot be ignored in the nearest future, naming it "one of the most decisive marketing conceptions of last times" 4 .

The results of research show that more and more Poles love games. The most favourite games are on-line ones. According to TNS OBOP in 2012 "as many as 77\% of Polish Internet users declared that they had ever played on-line, but one fifth of them had played more than once a day", . One year later, in 2013, according to the research conducted by Research NK and presented during game Industrial Trends, the amount of players had increased to $85 \%$.

Game Industrial Trends Report from 2014 shows how the profile of games users has changed $^{6}$ :

1. The participation of players in the age of $25-34$ has dropped from $95 \%$ to $89 \%$, but the participation of players $50+$ has increased.

2. As much as $80 \%$ of information about games is found from the Internet, $41 \%$ of it is achieved by search engine.

3. From $48 \%$ to $35 \%$ the meaning of social media has dropped.

4. $59 \%$ of men think that games have influenced their life positively.

5. Men play on laptops and PCs in so called shooting games, they chose more often sport games as well.

6. Women like mobile versions of games and games from search engines, they like more and more logical games and they choose them in social services.

With the development of modern technologies the number of people who use mobile devices is increasing. They use smartphones and tablets. The consumers like games and they play. That is why the marketers should use this fact and start to use game in their work in order to manage the relationship with customers and to build their involvement. "If these mechanisms work so well, that almost 20 million of people plant daily virtual vegetables enthusiastically in „FarmVille”, so why don't use them in the other boring but crucial spheres of life?"

The goal of this work is to show how one of the newest trends in marketing called gamification works and to show the possibilities of using games in the urban areas. In this study it is assumed that gamification can help with motivating the residents of cities and tourists to take care about the common space, involve them, teach and work out some proper habits.

\section{THE MATTER OF GAMIFICATION}

Gamification is the process of implementation the structure and mechanism of game (points, badges, levels, challenges and prizes) to the real world in order to provoke the

\footnotetext{
${ }^{4}$ P. Tkaczyk, Grywalizacja. Jak zastosować mechanizmy gier $w$ działaniach marketingowych, Wyd. Helion, Gliwice 2012, p. 149-150.

${ }^{5} W$ co gramy $w$ sieci, http://media2.pl/internet/89586-TNS-OBOP-W-co-gramy-w-sieci.html access: 30.05.2014.

${ }^{6}$ Rynek gier się zmienia, http://grywalizacja24.pl/rynek-gier-sie-zmienia/ access: 5.10.2015.

${ }^{7}$ FarmVille - search engine game, which lets player transform in the role of virual farmer, integrated with social service Facebook, which allows to inform friends about activity, inviting them and other actions making the number of players bigger.

${ }^{8}$ Grywalizacja, czyli gamification po polsku, http://www.eksoconline.uni.lodz.pl/?p=882 access: 20.09.2015.
} 
involvement of users, to change their behaviour and to solve different types of problems 9 . Gamification is not only the act of promoting by introducing new brand to game, but also translation the mechanisms and involving the solutions from games to the real world, in the way to motivate and affect us. We can promote a brand; we can encourage and motivate the target group to take particular actions ${ }^{10}$. Paweł Tkaczyk claims that gamification means the using of mechanisms and techniques known from various types of games ( board, plot or computer ones) to increase the involvement of user in action in the situations which are not games, particularly, when they are thought to be boring and routine ${ }^{11}$. Unfortunately, this term is overused very often by specialists in marketing. Gamification is not typical loyalty program, where the producer persuades people to collect stamps, which we can exchange for a prize. In the gamification such elements like points, rewards, ranks, results tables, plot, and communication systems between players. "The working of this loop is very easy, even banal: customers, who take actions crucial for us (buy, for instance), take decisions important for us and get from us positive reinforcement (points, badges etc.) The achievement of next points and badges is connected with next positive reinforcement (we give customers something more, that they expect), so we motivate people to take next actions crucial for us" ${ }^{12}$.

\section{TOOLS OF GAMIFICATION}

The matter of gamification consists in building the involvement and strong emotions between the receiver of message (a purchaser, an employee, and partner) and a brand, product or service. These emotions appear when the plot of game is built. P. Tkaczyk mentions about "designing of curiosity” to help a person with „going deeper” in the game, to make it multilevel and giving a lot of different possible solutions. "On the base of analysis of successful projects 3 pillars are determined, which are the guarantee of success, so strong and long-lasting involvement of participants:

- Fun - understood by satisfaction, not only connected with something funny. It is momentary entertainment giving the pleasure.

- Friends - the possibility of fun in community, inviting friends, meeting new people, cooperation and competing. It is fulfilling of human need to make friends and keeping in touch with other people, feeling of belonging to community is a key to success social games, but also projects based on crowdsourcing ${ }^{13}$.

\footnotetext{
${ }^{9}$ K. Wrona, Grywalizacja i gry oraz ich potencjat do wykorzystania w strategiach marketingowych, „Marketing i Rynek", nr 10/2013, s. 25.

${ }^{10}$ Raport Game Industry Trendy 2012, http://www.git2012.pl/raport access: 25.08.2015.

${ }^{11}$ M. Laskowski, Wykorzystanie czynników grywalizacyjnych $w$ tworzeniu aplikacji użyteczności publicznej, Zeszyty Naukowe Uniwersytetu Rzeszowskiego, https://www.ur.edu.pl/file/57419/2.pdf, access:1.10.2015.

12 Założenia grywalizacji dla budowania lojalności, http://grywalizacja24.pl/zalozenia-grywalizacji-dlabudowania-lojalnosci-klienta/ access: 31.08.2015.

${ }^{13}$ Crowdsourcing- outsourcing of work a group of people instead of basing on traditional system of working appointing work to narrow group of specialists. Crowdsourcing is appointing tasks provided for small group of people to undetermined crowd: Internet users, consumers, volunteers. "Crowd" can be rewarded for doing its tasks, but not has to. A lot of people decide to share their knowledge, talents for free. They have satisfaction from working for society. Crowdsourcing can be smartly transformed as a part of gamification and encourage people to share their time and knowledge with playing and competing in the same time [Source: http://grywalizacja24.pl/crowdsourcing/ access 25.08.2015].
} 
- Feedback - receiving by users fast back information about their actions"14.

Plot of game should be lined by special tools maintaining the competition, fun, communication and interactions between players. Pawel Tkaczyk mentions that the basic elements influencing on the users motivation and being part of game structure is as follows:

- Rewards. They are the most often in the form of points, but it is advised to adjust the form of rewards to the plot of game and given story

- Feedback, thanks to which a player can be informed about their achievements (sometimes in the comparison with the results of other players) in a clear and fast way.

- Statuses and levels. The levels provide permanent interest in game, and the passing from one level to another is the goal itself. The achieving particular level is visible in the status of player, who can be the motivator for the other players in taking next actions.

- Achievements and challenges, which prevent people from „go away” from a game and whose achieving make players be closer to the finish of particular level of game. Thanks to overcoming the difficulties a player gets the feeling of satisfaction and willingness to solve next task. It is important to provide new, different challenges, which can involve the players and take their attention.

- Table of results. The possibility of comparing results favours the competition and defeating others.

- Virtual possessions and places, thanks to which the users can express themselves and make friends with other players. Here we can mention virtual presents and other mechanisms supporting altruism and helping others ${ }^{15}$.

There are a lot of spheres where the gamification can be used: sale, education and trainings, brand promotion, product promotion, recruitment, administration and management.

It is worth mentioning that not all things which we can play in, can be called gamification. It is not loyalty program and city game as well ${ }^{16}$. There are all 3 elements (Fun, Friends, Feedback), but every city game finishes very fast, but the gamification is longlasting involvement of players.

\section{TYPOLOGY OF PLAYERS}

According to R. Bartle, the author of „Games People Play” a professor of Essex University, players expect from virtual world the following profits:

- discovering the world - it is crucial for those, who like visiting virtual world and learn about its laws,

- achievements inside game - it is important for those, who realise the goals pointed by game consistently and want to do their best in playing,

\footnotetext{
${ }^{14}$ S. Starzyński, Gryfikacja, modny termin nadużywany przez marketerów, http://www.git2012.pl/raport access: 25.08.2015.

${ }^{15}$ B. Jaskowska, $W$ to nam graj! Grywalizacja w promowaniu uslug bibliotecznych. Biblioteka jako marka: materiały z VII Forum Młodych Bibliotekarzy w Łodzi, 11-12 września 2012 r., http://repozytorium.ur.edu.pl /bitstream/handle/item/127/Grywalizacja_BJaskowska.pdf?sequence=1, access: 1.10.2015.

${ }^{16}$ City game - a form of entertainment using the city area where participants have particular tasks such as solving problems, looking for hidden places, gaining points and rewards.
} 
- coming into contact with others - a key for those who like contacts, conversations, which can be transferred to the real world,

- influencing other people - important for those, who like chaos, challenge the others, rob and kill ${ }^{17}$.

In this way we can determine four basic types of players by theirs motivation and behaviours in virtual world:

1. Explorers - gain the experience, go sightseeing around virtual world, they want to learn about it as much as possible.

2. Archivers - collect points, like games with results tables and levels.

3. Socialisers - gain the social experience, the game is for them an introduction to longlasting social interactions. They care about other players; a game itself is for them some kind of background for meeting interesting people

4. Killers - they are interested in loosing of other players. They care about their power over the others ${ }^{18}$.

\section{GAMIFICATION IN THE URBAN AREA}

Gamification in the urban area is the one of change directions, to which city marketing is going to head to. It is about increasing involvement of participants in city promotion or learning about its history, involving participants in caring about the aesthetics of city and creating its facilities. Among some interesting examples of gamification connected with urban area are presented:

1. Application CivCity which is created to activate the residents of American city Ann Arbor. „The whole is based on the assumption that the more aware residents are the more active ones. (...) The points in CivCity are collected for all activities connected with the city life - cleaning the area or taking part in events organised in Ann Arbor. The project has got function responsible for improving the local business, as well"19.

2. Recuperator is an idea connected with dogs' droppings in the urban area. This idea has appeared as a result of Think Blue action ${ }^{20}$, which the goal was the working out of actions influencing the comfort of life in small communities. It was the idea of Volkswagen Company and it the idea of dogs' recuperator succeeded. „The working of recuperator is simple. After bringing packed droppings, a minder of an animal can become a player by getting a chance for winning an ecological gadget" 21 .

3. Turkish company Pugedon tried to solve the problem of ownerless dogs and plastic bottles recycling. The containers, where people can put plastic bottles, are placed in Istanbul. There is a reward for every bottle, but this reward is given to ownerless dogs. There is food and water for dogs in containers, which is dispensed every time when an empty plastic bottle is placed there. In this way the company wants to remind people

\footnotetext{
${ }^{17}$ P. Tkaczyk, Grywalizacja. Jak zastosować.., p. 78.

${ }^{18}$ P. Tkaczyk, op.cit., p. 78.

${ }^{19}$ Grywalizacja w mieście, http://grywalizacja24.p1/grywalizacja-w-miescie/ access: 1.10.2015.

${ }^{20}$ The action was a part of global campaign Think Blue by Volkswagen, during which over 350 projects were realised in 35 countries. There are another kinds of them planned in Poland.

${ }^{21}$ Rekuperator - grywalizacja sprzatania, http://grywalizacja24.pl/rekuperator-grywalizacja-sprzatania/ access: 1.10.2015.
} 
about ecology and teach them sensitivity to homeless animals ${ }^{22}$. The shot of the poster is presented at Picture 1.

Picture 1. Action with the elements of gamification in Istanbul

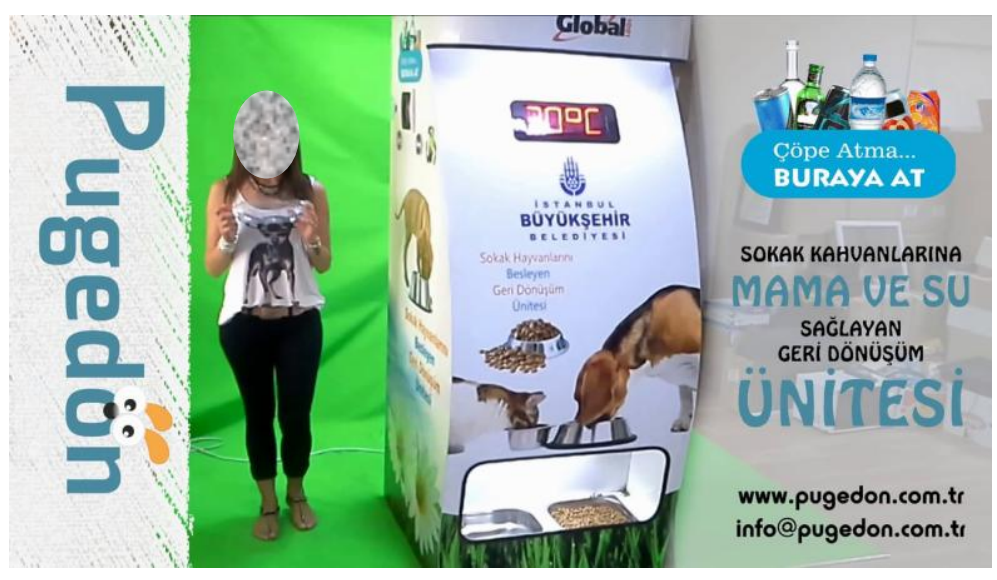

Source: http://pugedon.com/tr/ access: 1.09.2015

4. A ticket for 30 knee bends - this action with the elements of gamification was organised in underground in Moscow (Picture 2). This action was part of physical activity and Winter Olympic Games in Sochi in 2014. At one station of Moscow underground a ticket machine was installed. It attracted people. A lot of passers- by stopped to support exercising residents of Moscow.

Picture 2. Action with the elements of gamification in Moscow underground

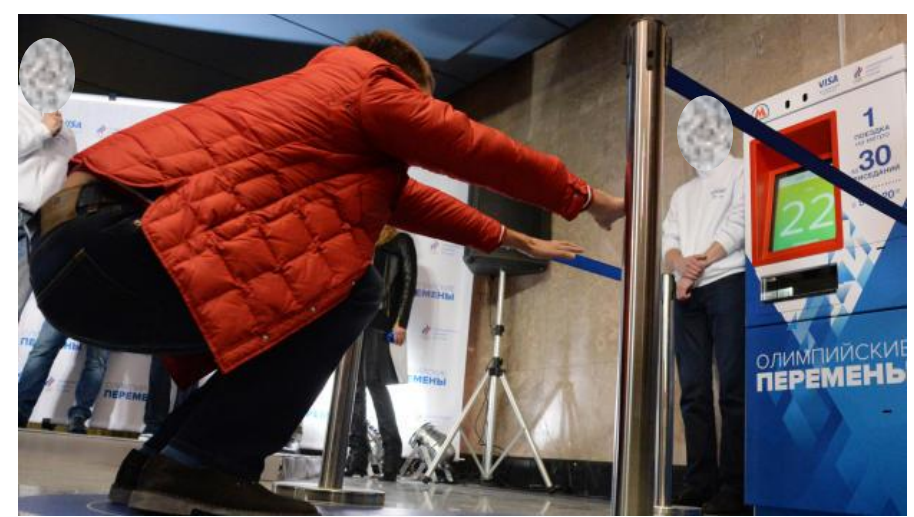

Source: http://www.gamification.co/2013/11/15/squat-30-times-free-metro-pass/ access: 1.10.2015.

22 Zużyte butelki karmiq bezdomne psy, http://www.kampaniespoleczne.pl/kampanie,3274,zuzyte _butelki_karmia_bezdomne_psy, access: 1.09.2015. 
5. Bottle Bank Arcade - action to increasing the amount of glass for recycling. In this project "it was proved that the fun was the factor which motivates people to work out positive, healthy habits. Bottle Bank Arcade was created in Sweden in 2009 and it was based on gamification. Instead of using virtual badges, points or rewards giving for passing missions, the authors of project presented the disinterested fun, which caused the joy. (...)Bottle Bank Arcade was nothing more like machine "on steroids" used for recycling. The authors put there blinking lamps and speaker taking the passers-by' attention, the bottom of START and the counter of points gained by people who took part in this fun. After starting the machine, installed lamps which there are holes for glass bottles under, blinked randomly. The task of players was efficient putting the glass bottle to active holes (blinking lamps). For each correct bottle placing the player got one point, which is showed by electronic counter"23.

6. Another action encouraged to physical activity (Picture 3). This time French producer of mineral water Nestle Waters the owner of Contrex brand, there was a project encouraging women to use pink stationary bikes placed in one street. When women sit and started to pedal the energy made by this action powered the light show. There was neon stripteaser presented on the wall and it was enough to pedal more. There was smartphone application joined with this action "for all who are fed up with losing weight. You can dance, sing, watch films and burn calories in the meantime. The application counts on the base of simple life activities how much calories you have burned" 24 .

Picture 3. Action with the elements of gamification by Contrex Nestle Waters

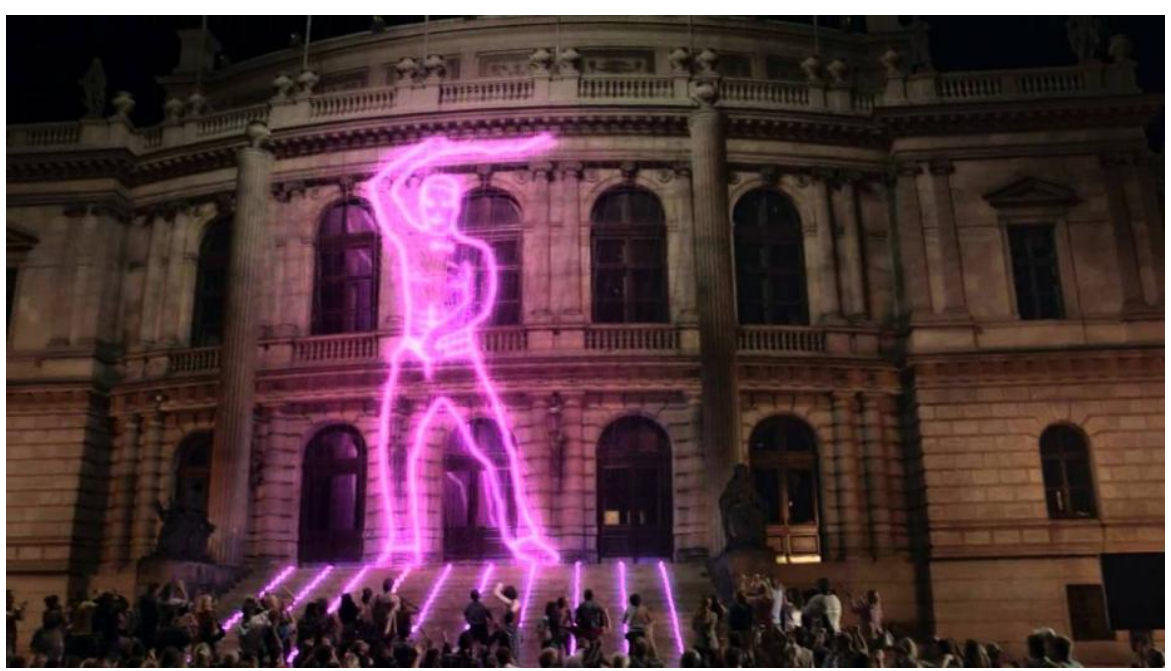

Source: http://przerwanareklame.pl/artykuly/reklama-wody-mineralnej-jakiej-swiat-jeszcze-niewidzial/ access: 1.10 .2015 .

\footnotetext{
${ }^{23}$ Bottle Bank Arcade, http://grywalizacja24.pl/bottle-bank-arcade/ access: 1.10.2015.

${ }^{24}$ Reklama wody mineralnej jakiej świat nie widziat, http://przerwanareklame.pl/artykuly/reklama-wodymineralnej-jakiej-swiat-jeszcze-nie-widzial/ access: 1.10.2015.
} 
7. "Piano stairs" w Stockholm - gamification is used in promoting healthy lifestyle. Project with the elements gamification was executed at Odenplan in Stockholm in the form of Piano Stairs (Picture 4). The authors of project wanted to encourage people to be more active, installed project imitating the piano keys. At the beginning people observed the situation and chose an escalator, but after some time as many as $66 \%$ of passengers had fun with piano stairs".

Picture 4. Action with the elements of gamification in Stockholm
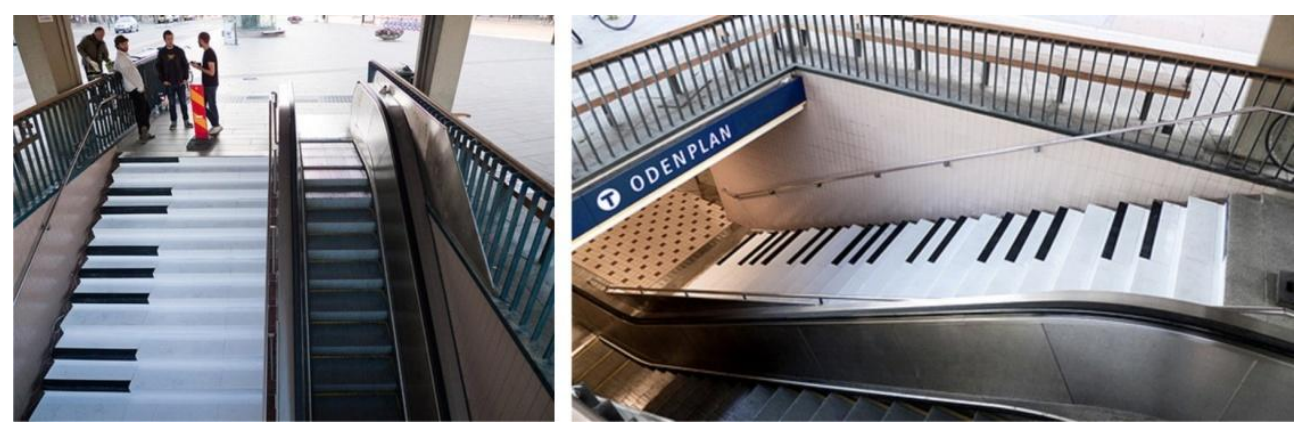

Source: http://www.thefuntheory.com/ access: 10.09.2015.

Gamification and the elements of games are more often used in the connection with other tolls. For example in tourism and city promotion gamification can be used with storytelling $^{25}$ and questing ${ }^{26}$. The example of questing used in the urban area is „, Royal Quest Poznan", which leads the participant of the fun through the streets of Old Town in Poznan showing known places but in different way.

There are riddles and tasks, which at the end lead to the place where a case with treasure is hidden. To complete total task a participant has to put a password from collected letters",27.

\section{CONCLUSIONS}

Undoubtedly, gamification is an interesting trend and how it was shown in the examples above; it can have positive influence on involvement of participants and their experiences. The proper implementation of game mechanisms during the process of gamification can considerably influence the increasing of results (the involvement of participants, for instance). We should remember that we cannot use it as an only tool or remedy for all problems. Not every solution should be practiced in urban area. Marketers and local authorities are responsible for tools and time which they choose. All actions should be integrated in such way that that can be solid element of urban area promotion.

\footnotetext{
${ }^{25}$ Storytelling - narrative marketing, telling the story to involve participants in project.

${ }^{26}$ Questing another words tourism with riddles- it is the form of turism with using quests - paths which lead according to clues hidden in the map. Questing is more and more popular in Poland. More and more marketing specialists use it

27 Quest Królewski Poznań, http://www.poznan.pl/mim/turystyka/quest-krolewski-poznan,p,23594,23599, 23604.html access: 10.09.2015.
} 


\section{REFERENCES}

[1] Bottle Bank Arcade, http://grywalizacja24.pl/bottle-bank-arcade/

[2] Grywalizacja, czyli gamification po polsku, http://www.eksoconline.uni.lodz.pl/?p=882

[3] Grywalizacja w mieście, http://grywalizacja24.pl/grywalizacja-w-miescie/

[4] Jaskowska B., W to nam graj! Grywalizacja w promowaniu ustug bibliotecznych. Biblioteka jako marka: materiały z VII Forum Młodych Bibliotekarzy w Łodzi, 11-12 września 2012 r., http://repozytorium.ur.edu.pl/bitstream/handle/item/127/Grywalizacja_BJaskowska.pdf?seque nce $=1$

[5] Laskowski M., Wykorzystanie czynników grywalizacyjnych $w$ tworzeniu aplikacji użyteczności publiczne, Zeszyty Naukowe Uniwersytetu Rzeszowskiego, https://www.ur.edu.pl/file/57419/ 2.pdf

[6] Raport Game Industry Trendy 2012, http://www.git2012.pl/raport

[7] Reklama wody mineralnej jakiej świat nie widziat, http://przerwanareklame.pl/artykuly/ reklama-wody-mineralnej-jakiej-swiat-jeszcze-nie-widzial/

[8] Rekuperator - grywalizacja sprzątania, http://grywalizacja24.pl/rekuperator-grywalizacjasprzatania/

[9] Rynek gier się zmienia, http://grywalizacja24.pl/rynek-gier-sie-zmienia/

[10] Tkaczyk P., Grywalizacja. Jak zastosować mechanizmy gier $w$ działaniach marketingowych, Wydawnictwo Helion, Gliwice 2012.

[11] W co gramy w sieci, http://media2.pl/internet/89586-TNS-OBOP-W-co-gramy-w-sieci.html

[12] Wrona K., Grywalizacja i gry oraz ich potencjat do wykorzystania w strategiach marketingowych, „Marketing i Rynek” 2013, nr 10, s. 25-31.

[13] Założenia grywalizacji dla budowania lojalności, http:/grywalizacja24.pl/zalozeniagrywalizacji-dla-budowania-lojalnosci-klienta/

[14] Zużyte butelki karmia bezdomne psy, http://www.kampaniespoleczne.pl/kampanie, 3274,zuzyte_butelki_karmia_bezdomne_psy

\section{GRYWALIZACJA W PRZESTRZENI MIEJSKIEJ}

Czy grywalizacja może stać się nośnikiem informacji w przestrzeni miejskiej? Współcześni klienci są atakowani komunikatami reklamowymi ze wszystkich stron. Większość z tych komunikatów, świadomie lub nie, pozostaje niezauważona. Twórcy projektów reklamowych poszukują sposobów na dotarcie do odbiorców w zalewającym nas ze wszystkich stron szumie informacyjnym. Trudności pojawiają się również w dotarciu z przekazem do potencjalnych odbiorców kampanii promujących różnego rodzaju działania w przestrzeni miejskiej. Mowa tu o promowaniu miasta jako atrakcji turystycznej, przybliżaniu historii czy angażowaniu mieszkańców w dbałość o zachowanie estetyki miejsca. Innym, przemawiającym za grywalizacją argumentem, jest rosnąca rzesza osób zainteresowanych grami. Według badań coraz więcej osób jako formę rozrywki wybiera różnego rodzaju gry. Uwielbiamy rywalizować. Pociągają nas zdobywane poziomy, odznaki i nagrody. A jeśli to wszystko dzieje się w jakiejś określonej, dopingującej nas do działania, społeczności w atmosferze zabawy, zaangażowanie w gre pojawia się automatycznie. Duże zainteresowanie grami i ich mechanizmami zaczyna się przekładać na inne obszary. Grywalizacja i elementy gier są coraz częściej wykorzystywane w zarządzaniu relacjami z nabywcami i budowaniu ich zaangażowania. Grywalizuje się również działania związane z sprzedażą, edukacją i szkoleniami, promocją marki, promocją produktu, rekrutacją, w administracji i zarządzaniu. Celem opracowania było przedstawienie istoty koncepcji grywalizacji i z akcentem na działania związane $\mathrm{z}$ grywalizowaniem przestrzeni miejskiej. Założono, że grywalizacja może pomóc zmotywować mieszkańców miasta i turystów do dbania o wspólną przestrzeń, 
zaangażować oraz wypracować właściwe nawyki i postawy. Pracę uzupełniono przykładami zastosowania grywalizacji w przestrzeni miejskiej.

Słowa kluczowe: grywalizacja, przestrzeń miejska, zaangażowanie nabywców, zarządzanie relacjami, marketing

\section{DOI: 10.7862/rz.2016.mmr.36}

Tekst złożono w redakcji: kwiecień 2016

Przyjęto do druku: sierpień 2016 